\title{
Probiotics in Brackish Water Fish Farming: A Special Focus on Encapsulated Probiotics
}

\author{
Ihsana Banu Ishthiaq ${ }^{1}$ (i) , Jahangir Ahmed ${ }^{1}$ (i) , Karthikeyan Ramalingam ${ }^{\text {1, *i }}$ \\ 1 School of Life Sciences, B.S. Abdur Rahman Crescent Institute of Science and Technology, Chennai, Tamil Nadu, India \\ * Correspondence: karthikeyan.sls@crescent.education;
}

Scopus Author ID 43961552400

Received: 25.01.2021; Revised: 7.03.2021; Accepted: 12.03.2021; Published: 31.03.2021

\begin{abstract}
In GMOs' age, pesticides, contaminants, and other anthropogenic practices move towards an environmentally sustainable solution. Aquaculture is one of the fastest-growing food sources connected with several challenges. Aquaculture industries are required to produce food with a better state of health and environmentally friendly. The encapsulation of probiotics in the aquatic feed addresses various problems as many probiotic organisms are shown to strengthen immunity, improve growth, survival, and reproduction of many fish species, including brackish water fish. By including certain probiotics as a food additive, the well-being of aquatic organisms can be enhanced. This review summarizes probiotics' inclusion in an encapsulated form in aquatic feed formulation for enhancing brackish water fish culture.
\end{abstract}

Keywords: probiotics encapsulation; brackish aquaculture; growth immunity; reproduction.

(c) 2021 by the authors. This article is an open-access article distributed under the terms and conditions of the Creative Commons Attribution (CC BY) license (https://creativecommons.org/licenses/by/4.0/).

\section{Introduction}

The concern to reduce the use of chemicals and transition to environmentally sound practices has increased in recent years. Among the food-producing industries, aquaculture has cropped up as an essential food source for animal protein. Aquaculture is encouraged as it has lower greenhouse gas emissions than any other type of farming; it reduces overfishing and nonselective fishing, preventing under a population of many aquatic species [1-2]. The ultimate goal of the aquaculture industry is to increase productivity sustainably.

Brackish aquaculture is encountering several challenges, such as disease control, health management, survival, and reproduction which are being resolved by applying antibiotics, vaccines, chemicals, medicines, and other supplements. The use of these improvement strategies for better production has caused accumulation, biomagnification, and also the development of antibiotic-resistant pathogens. The use of antibiotics is not preferred as it devastates the gut microbiota flora along with the pathogenic bacteria, suppresses the immunity, and has a detrimental effect on the ecosystem and food safety concerns [3-4]. Thus, increasing need can be satisfied only by practicing brackish aquaculture sustainably with environmentally friendly approaches [5-6]. Moreover, young fish do not have a strong immune system; thus, they do not respond well to vaccines [7-8]. Hence, the alternative option for vaccines is probiotics, and it is live microorganisms that are largely beneficial to the host [9]. The advent of probiotics was an environmentally friendly replacement for antibiotics, chemicals, and pesticides. Probiotic feed improves the aquatic 'animals' gut microbiota and enhances survival, digestion, growth, immunity, resistance to disease, and reproduction when 
administered appropriately. Fish larvae and fingerlings have an immature digestive system and are poor in digestive capacity. The addition of probiotics to the fingerlings and fish larvae in their feed allows them to overcome this issue.

It has been evidenced that probiotics in the aquatic feed formulation have improved the quality of brackish aquaculture. The delivery mode can be direct addition in the culturing water, as pellets, encapsulating, via live feed by bio-encapsulation and injection $\quad[1,10$ 11]. Although, encapsulate feed is considered more efficient, it ensures delivery in preferred quantity, protecting the probiotics from the harsh gastric environment or deterioration by water, temperature, and effective carriage into the intestine [12].

The objective of this review is to cover the modes of actions of probiotics in cultivable brackish water fish, including fresh water and marine fish that can also be farmed in brackish water due to their strong ability to withstand variation in salinity [13-14]. The survival, growth, immunity, and reproduction enhancement after introducing probiotics in the feed and preparation of effective probiotics encapsulated feed for the same will be reviewed.

\subsection{Mode of action of probiotics.}

Probiotics have an overall effect on fish life cycle, as shown in Figures 1 and 3. The digestive system is undeveloped and immature in the larvae and fingerlings of fish. They will not be able to efficiently digest food and consume nutrients, slowing down their growth process. Probiotics release exogenous digestive enzymes and enable the gut zymogens that improve digestion, increases protein availability by proteolysis, release amino acids, vitamins [2]. Probiotics have also been studied to increase the height of villi in the intestine. An increase in villi height successively increases the intestine's surface area in Oreochromis niloticus (Nile tilapia) was observed when administered with alginate encapsulated Lactobacillus rhamnosus and Saccharomyces cerevisiae JCM 7255 [15-16]. Effective absorption of micronutrients, survival, and growth was also observed in Sparus aurata (Gilthead bream) larvae and fingerlings when bio encapsulated Bacillus sp. R2 and Planococcus sp. R11 was supplemented [17-18]. Probiotics have been applied successfully to increase the survival, productivity, and decreased mortality of several fish and shrimp species. The immune system is vulnerable in the early life stages of fish and is more susceptible to attack by various pathogens. Probiotics have been widely researched as antimicrobial and can thus be substituted for antibiotics. They prevent pathogenic bacteria's invasion by vying for adhesion sites in the epithelial mucosa of the intestine, nutrition, and the synthesis of antimicrobials. Besides adhesion sites, nutrition probiotics also compete for iron salts called siderophores. Probiotics that dominantly utilize siderophores effectively inhibit the survival of pathogens [19-20]. The 'host's immune system is activated and remains active, which reduced the immune response time; it also acts as an immune modulator and immunostimulant [1]. Oreochromis niloticus, Epinephelus coioides larvae, Poecilia latipinna, Sparus aurata L., and other fishes administered with encapsulated probiotics have expressed enhanced immune system in means of both specific, non-specific immunity and cellular and humoral immunity [21]. The reproduction process was also reported to have increased in fish species after the administration of probiotics. As food absorption and nutrition are vital to any process, so it is for gametogenesis in reproductive. Reproductive health is vital in order to get a good yield. In fish, not all the gamates they produce are fertile due to improper nutrition, maturation, and other factors. Probiotics have ensured the stimulation of genes responsible for reproductive maturity and reproduction [22-23]. The body fat index plays an essential role in the sexual behavior in most species; thus, it is important to 
balance the dietary unsaturated fatty acids[24-26]. Highly unsaturated fatty acids and group B vitamins were observed to support egg development, provide high rates of energy for vitellogenesis and swamping. It is closely associated with gonadal maturation, which all ines with the onset of puberty. Probiotics have been researched to produce group B vitamins and increase the body fat index. The probiotic Lactobacillus rhamnosus has been reported to have a progressive outcome in the spermatogenesis in Anguilla anguilla (european eel), vitellogenesis, GSI (Gonadosomatic Index), oocyte maturation, egg quality, fecundity, fertilation rate, hatching rate, sex ratio, embryo survival and over reproductive performance in Danio rerio (zebrafish) [27-28]. Poecilia latipinna supplemented with bio encapsulated Saccharomyces cervisiae was evidenced to increase its average fecundity [27]. Schilbe mystus (butter catfish) fed with probiotics were witnessed to have significantly improved quality of gametes, fertilization rate, and hatching rate [29-30].

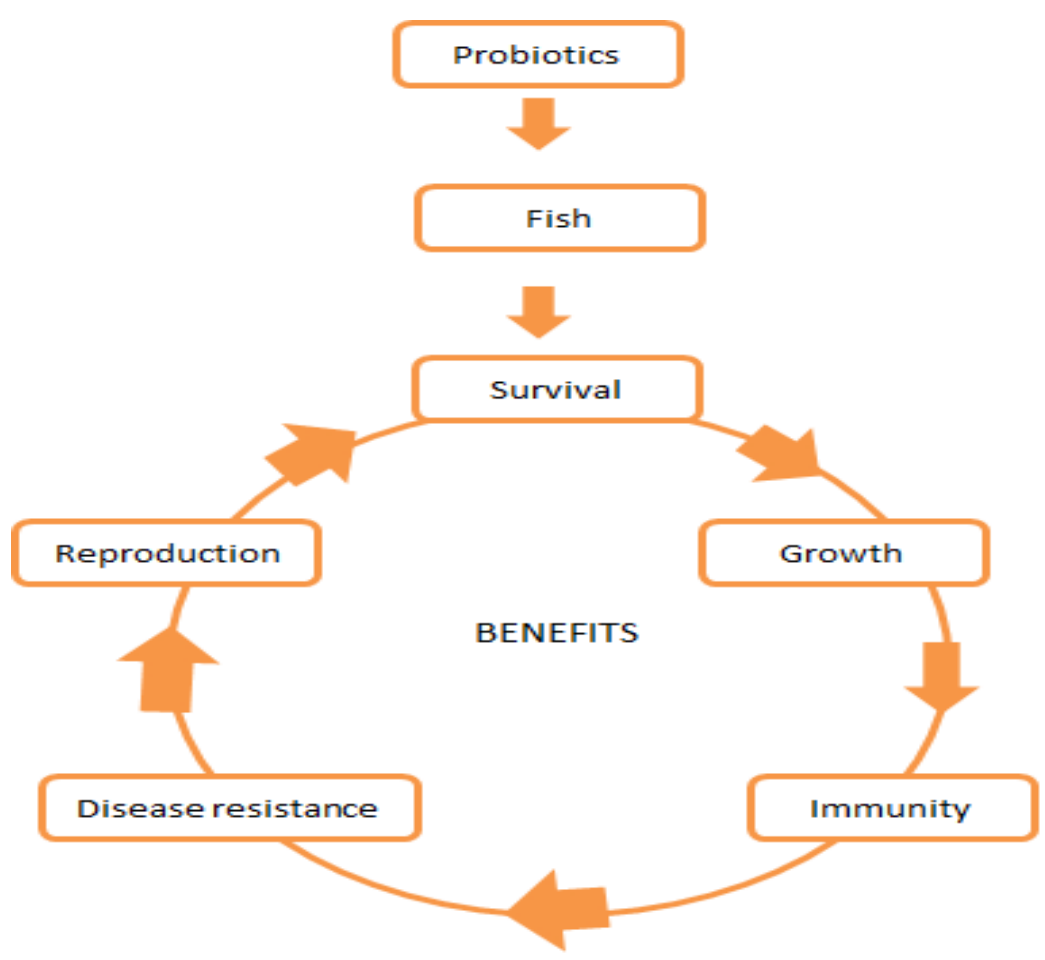

Figure 1. Fish administered with probiotics have been shown improvement in survival, growth, immunity, disease resistance, and reproduction.

\subsection{Gut of the fish.}

The anatomy of the fish gut is not standard. Some fish possess a pyloric area, gizzard, gall bladder, which may not be present in other fish species. There are also fish species that do not have a stomach. For example, mullets and sea bass have a pyloric area, blenny and goby have a gall bladder, lack stomach. The fish gut plays a predominant role in its immunity [3132]. Probiotics are associated with fish from their eggs stage. Bacteria are normally found in fish from their early stages. When the fish hatch, they tend to drink water to regulate the osmotic balance. In this process, the bacteria present in the water environment enter their gut and start to colonize [33]. Both probiotics and pathogenic bacteria are among these bacteria. In wild and farmed fish, the colonies of bacteria present differ variously. More aerobic bacterial species and very few or no anaerobic bacterial species can be seen as farmed fish are supplied with sufficient oxygen. Wild fish, on the other hand, have more anaerobic species of bacteria. From their water environment and food, fish derive the bacteria in their gut. The bacterial 
colonies are also complex since the diets of wild and farmed fish differ. The gut bacteria vary in inter-species also. Moreover, the bacterial species may be present in the stomach or midgut, or even hindgut. Similarly, the bacterial colony density also changes with the portion of the gut where they thrive. The bacterial may also live in a symbiotic relationship in the gut. The gut microbiota can be influenced efficiently to improve fish well-being [31].

\subsection{Selection of the probiotic strain.}

The selection of probiotics is a critical task when it comes to application. The probiotic strain playing a positive role in one host may not have any effect or can even have a negative impact on another host. Probiotics can be isolated from various areas such as fish gut, terrestrial hosts, water, soil, fermented food, etc. (figure 3). [33]. Bacteria isolated from the healthy gut of poultry chicken have been evidenced as effective probiotics in some fish varieties [34]. The probiotic should be well characterized and identified. The choice of probiotics for fish administration will be most preferred from the fish's aquatic environment. This is because the probiotics isolated from the native environment appear to have stronger promising characteristics than those extracted from any other environment. Also, the strains purposely introduced have been witnessed to vanish once the administration is withdrawn [35]. Even if the probiotic is isolated from another host, it should adapt and positively affect the new environment [36].

Resistance to the harsh $\mathrm{pH}$ and bile juice, the potential to bind to the mucosal surface of the intestine, a beneficial character to the host such as hindering the pathogenicity by competing with the pathogen or by synthesizing inhibitory compound, aiding digestion, functioning as an immunomodulant, etc., are the key characteristics expected in selecting a probiotic. The probiotics should also be tested, plated, or cultured in vitro conditions for commercial purposes, able to withstand preservation $[6,37]$. The characterization should be done by sequencing the 16sRNA. The antibacterial activity should be tested with various pathogens with agar well, and the spot lawn technique [28], viability, and other properties change after storage encapsulation should be checked in vitro. More importantly, the probiotic used should not be pathogenic to the host [38].

\section{Encapsulation}

Encapsulation is the idea of immobilizing or enclosing probiotics in a capsule which may be a live prey or a polymer (Figure 2) for effective, confirmed delivery and controlled release [39-41]. When live prey is used, mainly rotifers, Artemia, and copepods, it serves a dual purpose [42]. The probiotics increase the prey's nutritive value [43-44] and enhance the fish's living (Table 1). The bio-encapsulated feed cannot be stored but has to be prepared instantly. Bio-polymer encapsulation involves the microencapsulation of probiotics into small oral beads made up of alginate, chitosan, agar, etc. [45]. These ensure the storage and viability of the probiotics for quite a long term [46]. The bacterial density for encapsulation was maintained between $10^{6}$ to $10^{10} \mathrm{CFU} / \mathrm{ml}$ [47] when the bacterial load was increased in tor, but larvae exhibited a lower feeding rate [48].

\subsection{Bio-encapsulation.}

Bio-encapsulation involves the incorporation of products into live prey, enriching them with products in order to deliver them to the host. Due to their small size, optimal nutrition, 
and ease in digestion, rotifers and Artemia are the most common life feed for fish larvae. These organisms can also be used to deliver probiotics to the fish in bio-encapsulated form. These organisms take up the bacteria by absorption or filtration of particles into their digestive tracks and exoskeletons in 48 to 10 hours. Encapsulating Bifidobacterium animalic and Lactobacillus johnsonni in arteria showed an increase in growth in Chirostoma jordani larvae (charal fish) in the early 30 days. However, a significant difference was noticed only after 60 and 90 days of feeding. The group of fish fed with Lactobacillus johnsonni presented slightly higher growth than the other [49]. Administration of sea bream larvae with bio encapsulated Planococcus to rotifers and Artemia significantly improved larval survival, length, weight, specific growth, protein, and lipid nutritional value. The protease activity, the number and length of the villi, and the number of goblet cells were significantly increased, suggesting an improvement in digestion and absorption. As the mode of distribution shifted, the range of growth varied significantly. Larvae fed with only live bio encapsulated probiotics had the greatest improvement compared to rearing and bio encapsulated plus rearing [17]. Molly fish (Poecilia latipinna) fed with Artemia enriched with Saccharomyces cervisiae reported enhancement in growth, survival, reproduction in terms of average fecundity, lysozyme activity, and immunity [27]. Although the impact of encapsulated probiotics is not yet advanced in the reproduction of brackish water fish. Rotifers treated with lactic acid bacteria were demonstrated to improve turbot larvae's growth and immunity [50].

\subsection{Microencapsulation.}

Microencapsulation involves the encapsulation of probiotics in bio-polymer matrices that are derived from sea algae, plants, or animals. Probiotics encapsulated using this technique are immobilized and targets the delivery of life probiotics [10]. This bio-polymer matrice is mostly non-nutritive and may act as an immunostimulant $[15,27$,$] .$

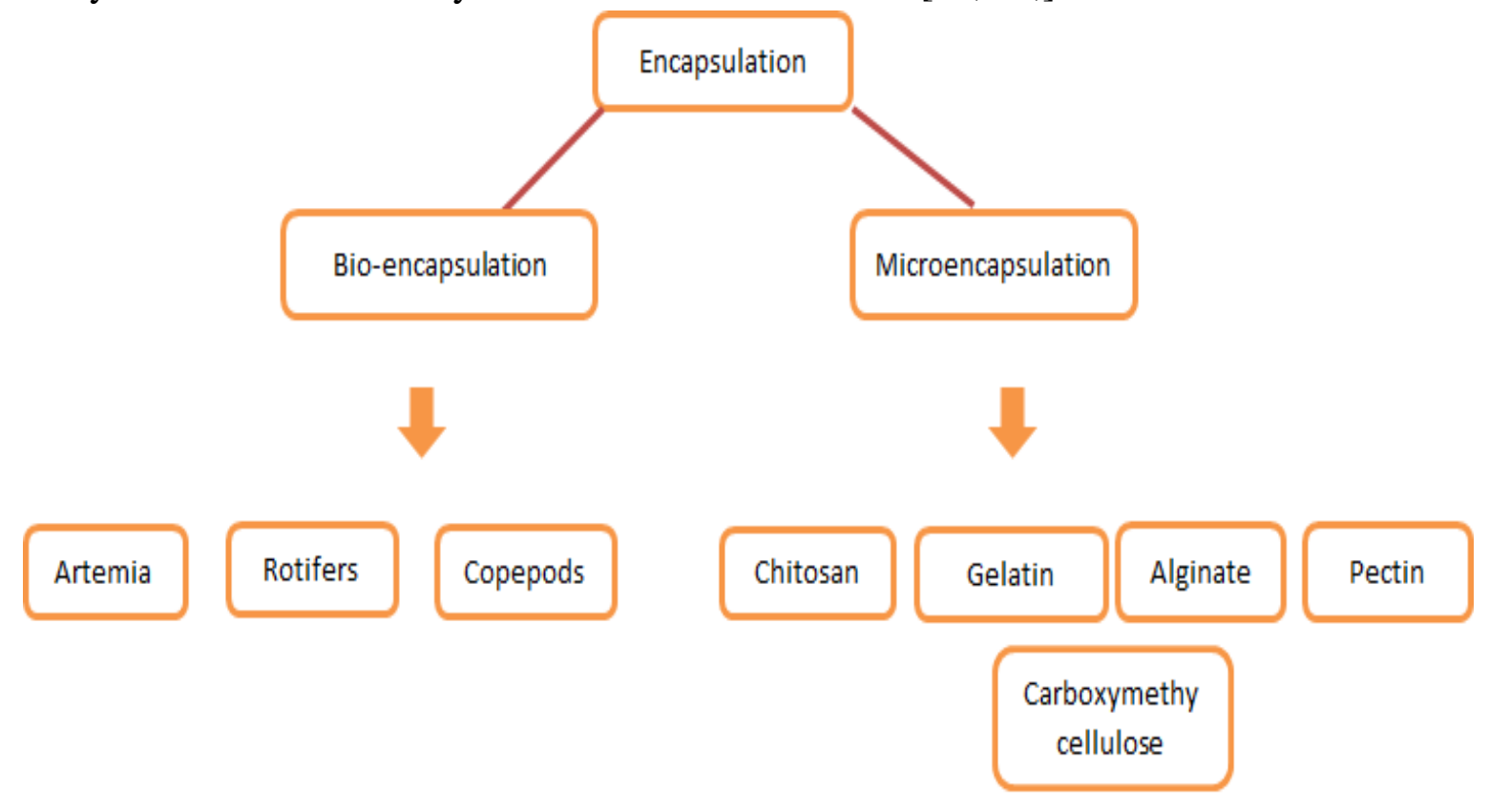

Figure 2. Various forms of encapsulations of probiotics as fish feed additives.

A study reported that the alginate of the microencapsulated beads had an immunostimulatory effect and served as a prebiotic in fish [51-52]. Unlike freshwater fish, a microencapsulated feed can be efficiently digested by marine fish or brackish water fish [50]. 
These capsules release the probiotics gradually into the gut [53]. Microencapsulation provides the advantage of encapsulating other feed and probiotics such as plant extracts, lipids, proteins, etc. in appropriate compositions as a source of prebiotics [54-55]. Prebiotics are compounds that benefit the probiotics and also the host acting as immunostimulants [56]. In calcium alginate encapsulation, a higher concentration of calcium ion has negatively affected bacterial viability. Hence, a calcium chloride concentration of less than $3 \%$ was preferred. Microencapsulation also has the flexibility to produce capsules of desired and determined size, shape, thickness, and bacterial density. These capsules are resistant to the stomach's pH, withstand temperature, and appropriate for storage and transport [7, 46].

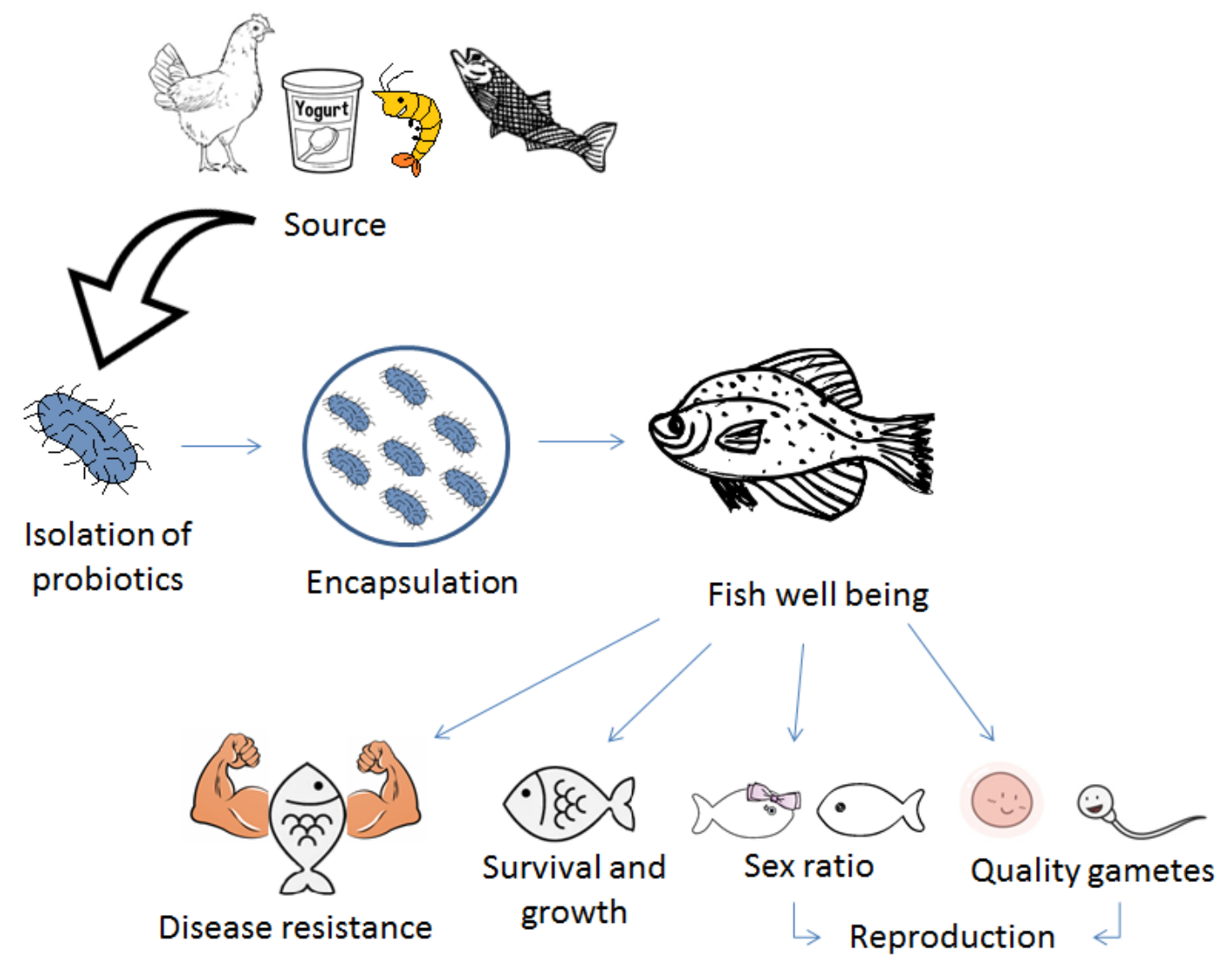

Figure 3. Well being of the fish in terms of reproduction, survival, and growth, disease resistance after applying encapsulated probiotics isolated from various sources.

Table 1. Benefits of various encapsulated probiotics on brackish water farmed fishes.

\begin{tabular}{|c|c|c|c|c|c|}
\hline $\begin{array}{l}\text { SI. } \\
\text { No. }\end{array}$ & $\begin{array}{l}\text { Probiotic } \\
\text { strain }\end{array}$ & Host & Encapsulated form & Benefit & Reference \\
\hline 1. & $\begin{array}{l}\text { Lactobacillus } \\
\text { rhamnosus }\end{array}$ & $\begin{array}{l}\text { Oreochromis } \\
\text { niloticus }\end{array}$ & $\begin{array}{l}\text { Alginate } \\
\text { encapsulation }\end{array}$ & $\begin{array}{l}\text { Increased growth, higher villi height, acidophilic } \\
\text { granulocytes, intraepithelial lymphocytes and } \\
\text { mucous cells, Resistance against } S \text {. agalactiae }\end{array}$ & [16] \\
\hline 2. & $\begin{array}{l}\text { Lactobacillus } \\
\text { rhamnosus }\end{array}$ & $\begin{array}{l}\text { Oreochromis } \\
\text { niloticus } \\
\text { Juveniles }\end{array}$ & $\begin{array}{l}\text { encapsulated with } \\
\text { fat vegetable } \\
\text { matrices }\end{array}$ & $\begin{array}{l}\text { Increase in body weight and length, reduced } \\
\text { potential pathogens, up-regulation of npy, agrp, } \\
\text { and ghrelin and the decrease of leptin increasing } \\
\text { the feeding rate }\end{array}$ & [57] \\
\hline 3. & $\begin{array}{l}\text { Saccharomyces } \\
\text { cerevisiae }\end{array}$ & $\begin{array}{l}\text { Oreochromis } \\
\text { niloticus }\end{array}$ & $\begin{array}{l}\text { Alginate } \\
\text { encapsulation }\end{array}$ & $\begin{array}{l}\text { Increased weight, specific growth rate, } \\
\text { Resistence against Streptococcus agalactiae, } \\
\text { increased villi height, acidophilic granulocytes, } \\
\text { intraepithelial lymphocytes and mucous cells }\end{array}$ & [15] \\
\hline 4. & Bacillus sp. NP5 & $\begin{array}{l}\text { Oreochromis } \\
\text { niloticus }\end{array}$ & $\begin{array}{l}\text { Maltodextrin } \\
\text { encapsulation }\end{array}$ & $\begin{array}{l}\text { Resistance against Streptococcus agalactiae, } \\
\text { increased } \mathrm{Hb}, \mathrm{Ht} \text {, and EC }\end{array}$ & [47] \\
\hline 5. & $\begin{array}{l}\text { Saccharomyces } \\
\text { cerevisiae JCM } \\
7255\end{array}$ & $\begin{array}{l}\text { Oreochromis } \\
\text { niloticus }\end{array}$ & $\begin{array}{l}\text { Alginate } \\
\text { encapsulation }\end{array}$ & $\begin{array}{l}\text { Resistance against Streptococcus agalactiae, } \\
\text { increased villi height, acidophilic granulocytes, } \\
\text { interaepithelia lymphocytes and mucous cells }\end{array}$ & [58] \\
\hline
\end{tabular}




\begin{tabular}{|c|c|c|c|c|c|}
\hline $\begin{array}{l}\text { SI. } \\
\text { No. }\end{array}$ & $\begin{array}{l}\text { Probiotic } \\
\text { strain }\end{array}$ & Host & Encapsulated form & Benefit & Reference \\
\hline 6. & $\begin{array}{lr}\text { Bacillus } & \text { clausii } \\
\text { DE5 } \quad \text { and } \\
\text { Bacillus } \\
\text { pumilus } & \text { SE5 }\end{array}$ & $\begin{array}{l}\text { Epinephelus } \\
\text { coioides } \\
\text { larvae }\end{array}$ & $\begin{array}{l}\text { Bio-encapsulated in } \\
\text { copepods(Pseudodi } \\
\text { aptomus } \\
\text { annandalei) }\end{array}$ & $\begin{array}{l}\text { Increase in body weight, survival, increased } \\
\text { AKP activity, Lysozyme activity }\end{array}$ & [59-60] \\
\hline 7. & $\begin{array}{l}\text { Bacillus subtilis, } \\
\text { Bacillus } \\
\text { licheniformis } \\
\text { and Bacillus } \\
\text { pumilus }\end{array}$ & $\begin{array}{l}\text { Sparus aurata } \\
\text { larvae }\end{array}$ & $\begin{array}{l}\text { Bio-encapsulated in } \\
\text { Artemia and rotifer }\end{array}$ & $\begin{array}{l}\text { Increase in body weight and standard length, } \\
\text { lower HSP70 gene } \\
\text { expression levels reduced GR levels }\end{array}$ & [61] \\
\hline 8. & $\begin{array}{l}\text { EcoPro } \\
\text { probiotic }\end{array}$ & $\begin{array}{l}\text { Rachycentron } \\
\text { canadum } \\
\text { larvae and } \\
\text { fingerlings }\end{array}$ & $\begin{array}{l}\text { Bio-encapsulation } \\
\text { in Artemia and } \\
\text { rotifer }\end{array}$ & Increased survival and production & [62] \\
\hline 9. & $\begin{array}{l}\text { L. delbrueckii } \\
\text { delbrueckii } \\
\text { (AS13B) }\end{array}$ & $\begin{array}{l}\text { Dicentrarchus } \\
\text { labrax }\end{array}$ & $\begin{array}{l}\text { Bioencapsulation in } \\
\text { rotifer and Artemia }\end{array}$ & $\begin{array}{l}\text { Increased standard length, body weight, IGF1 } \\
\text { mRNA, decreased MSTN mRNA }\end{array}$ & [63] \\
\hline 10. & $\begin{array}{l}\text { Shewanella } \\
\text { putrefaciens } \\
\text { Pdp11 }\end{array}$ & $\begin{array}{l}\text { Sparus aurata } \\
\text { L. }\end{array}$ & $\begin{array}{l}\text { Alginate } \\
\text { encapsulation }\end{array}$ & $\begin{array}{l}\text { Increased serum peroxidase activity, } \\
\text { upregulation of mhcIIa and tcrb, increased serum } \\
\text { IgM leve, enhanced innate immune }\end{array}$ & [45] \\
\hline 11. & $\begin{array}{l}\text { Bacillus sp. R2 } \\
\text { and } \\
\text { Planococcus sp. } \\
\text { R11 }\end{array}$ & Sparus aurata & $\begin{array}{l}\text { Bio-encapsulation } \\
\text { in Artemia and } \\
\text { rotifer }\end{array}$ & $\begin{array}{l}\text { Improved larval survival, length, weight, } \\
\text { specific growth, protein and lipid nutritional } \\
\text { value }\end{array}$ & {$[17]$} \\
\hline 12. & $\begin{array}{l}\text { Pediococcus } \\
\text { acidilactici and } \\
\text { Saccharomyces } \\
\text { cerevisiae }\end{array}$ & $\begin{array}{l}\text { Pollachius } \\
\text { pollachius } \\
\text { larvae }\end{array}$ & $\begin{array}{l}\text { Bio-encapsulation } \\
\text { in Artemia }\end{array}$ & Promoted growth & [64-65] \\
\hline 13. & $\begin{array}{l}\text { B. clausii DE5 } \\
\text { and } B \text {. pumilus } \\
\text { SE5 }\end{array}$ & $\begin{array}{l}\text { Epinephelus } \\
\text { coioides } \\
\text { larvae }\end{array}$ & $\begin{array}{l}\text { Bio-encapsulation } \\
\text { in copepod }\end{array}$ & $\begin{array}{l}\text { Increased body length and weight, resisted } \\
\text { pathogenic Vibrio sp. growth }\end{array}$ & [59] \\
\hline 14. & $\begin{array}{l}\text { Saccharomyces } \\
\text { cervisiae }\end{array}$ & $\begin{array}{l}\text { Poecilia } \\
\text { latipinna }\end{array}$ & $\begin{array}{l}\text { Bio-encapsulation } \\
\text { in Artemia }\end{array}$ & $\begin{array}{l}\text { Enhanced growth, survival, reproduction in } \\
\text { terms of average fecundity, lysozyme activity, } \\
\text { and immunity }\end{array}$ & [27] \\
\hline 15. & $\begin{array}{l}\text { Bacterial strain } \\
4: 44 \text { and PB52 }\end{array}$ & $\begin{array}{l}\text { Scophthalmus } \\
\text { maximus } L \text {. }\end{array}$ & $\begin{array}{l}\text { Bio-encapsulated in } \\
\text { rotifers }\end{array}$ & $\begin{array}{l}\text { Higher resistance to stress or infection by } \\
\text { pathogens }\end{array}$ & [48] \\
\hline 16. & $\begin{array}{l}\text { Vibrio strains, } \\
\text { PB } 1-11 \text { and PB } \\
6-1\end{array}$ & $\begin{array}{l}\text { Hippoglossus } \\
\text { hippoglossus }\end{array}$ & $\begin{array}{l}\text { Bio-encapsulated in } \\
\text { Artemia }\end{array}$ & Inhibition of a pathogenic Vibrio & [66] \\
\hline 17. & $\begin{array}{l}\text { Lactobacillus } \\
\text { spp. }\end{array}$ & $\begin{array}{l}\text { Sparus aurata, } \\
\text { L. }\end{array}$ & $\begin{array}{l}\text { Bio-encapsulation } \\
\text { Rotifera and } \\
\text { Artemia }\end{array}$ & $\begin{array}{l}\text { Increase in specific growth rate (SGR) and } \\
\text { survival, enhanced digestive enzyme activities }\end{array}$ & [67] \\
\hline 18. & EC5 & $\begin{array}{l}\text { Scophthalmus } \\
\text { maximus }\end{array}$ & $\begin{array}{l}\text { Bio-encapsulated in } \\
\text { Artemia and rotifers }\end{array}$ & $\begin{array}{l}\text { Better survival and mortality rate against AHL } \\
\text { molecules }\end{array}$ & [68] \\
\hline 19. & $\begin{array}{l}\text { Lactococcus } \\
\text { lactis subsp. } \\
\text { Lactis } \\
\end{array}$ & $\begin{array}{l}\text { Dicentrarchus } \\
\text { labrax larvae }\end{array}$ & $\begin{array}{l}\text { Bio-encapsulated in } \\
\text { Artemia }\end{array}$ & $\begin{array}{l}\text { Resistance against Vibrio anguillarum, better } \\
\text { survival and mortality rate }\end{array}$ & [69] \\
\hline 20. & $\begin{array}{l}\text { Pediococcus } \\
\text { acidilactici }\end{array}$ & Psetta maxima & $\begin{array}{l}\text { Bio-encapsulated in } \\
\text { rotifer }\end{array}$ & Positive prevention in colonization & [70] \\
\hline 21. & $\begin{array}{l}\text { Probiotic Alken } \\
\text { Clear-Flo® } \\
1006 \quad \text { (ACF- } \\
1006)\end{array}$ & $\begin{array}{l}\text { Rachycentron } \\
\text { canadum }\end{array}$ & $\begin{array}{l}\text { Bio-encapsulated in } \\
\text { rotifer }\end{array}$ & $\begin{array}{l}\text { Elimination of undesired bacteria, enhancement } \\
\text { in health }\end{array}$ & [71] \\
\hline
\end{tabular}

\section{Encapsulated and Non-Encapsulated Evaluation}

Encapsulated probiotics have been tested to be more effective than administration via non-encapsulation. Sea bream larvae group administered with encapsulated probiotics (Bacillus subtilis, Bacillus licheniformis, and Bacillus pumilus) form alone have shown higher body weight, total length, and IGFI gene expression than group administered with encapsulated probiotics and added to rearing water [61]. Another experiment with Seabream larvae also demonstrated the effectiveness of encapsulated probiotics in which the control group and probiotics added to the rearing tank alone had no significant difference. The encapsulated probiotics (Lactobacillus spp.) showed notably better results in terms of SGR and survival, 
enhanced digestive enzyme activities [67]. This outcome of encapsulated probiotics may be due to the probiotics' escaping from the gastric tract's severe $\mathrm{pH}$, assured delivery with an optimal concentration of the probiotics via encapsulation. Furthermore, encapsulated beads expressed thermal resistance than free probiotic (L. acidophilus) cells where encapsulated cells reduced by $1.99 \log$ cycles and free celled reduced by $5 \log$ cycles when open to $60{ }^{\circ} \mathrm{C}$ for 30 minutes [72-73]. Encapsulated chitosan double-coated bead expressed relatively higher heat tolerance ( 3 to $4 \log \mathrm{CFU} / \mathrm{ml}$ viability) even at $90{ }^{\circ} \mathrm{C}$ for 5 minutes than alginate encapsulated and non-encapsulated probiotics (no viability) [12].

\section{Conclusion}

Application of probiotics in brackish fish culture ambitions to promote food source with nutrition and safety. Probiotics are present in the gut of aquatic and terrestrial animals. Since ancient times, probiotics have been studied about their benefits, mode of action, and their supplementing them as a food additive. The introduction of probiotics is an environmentally safe and sustainable method. Encapsulated probiotics offer better results than non-encapsulated forms of application. When administered in encapsulated form, probiotics assure the delivery in the desired concentration by protecting the probiotics from devastating environments. Moreover, microencapsulation is benefits storage for commercial purposes. In brackish aquaculture, the probiotic dosage used may vary between $10^{6}$ to $10^{10} \mathrm{CFU} / \mathrm{ml}$ depending on the expected result and fish species. Probiotics have enormously positive effects on cultivated fish's well-being, such as digestion and absorption, survival and growth, immunity and disease resistance, reproduction. Thus remarkably improves the key goals- production and nutritive value in aquaculture sustainably.

\section{Funding}

This research was supported by the DST Science and Engineering Research Board (SERB), and the Ministry of Ayurveda, Yoga \& Naturopathy, Unani, Siddha and Homoeopathy (AYUSH) India.

\section{Acknowledgments}

The authors declare no acknowledgments.

\section{Conflicts of Interest}

The authors declare no conflict of interest.

\section{References}

1. Fernandes, S.; Kerkar, S. Chapter 14 - Bacterial probiotics over antibiotics: A boon to aquaculture. In: Advances in Biological Science Research. Meena, S.N.; Naik, M.M. Eds. Academic Press: 2019; pp. 215232, https://doi.org/10.1016/B978-0-12-817497-5.00014-8.

2. Vázquez-Silva, G.; Ramírez-Saad, H.C.; Aguirre-Garrido, J.F.; Mayorga-Reyes, L.; Azaola-Espinosa, A.; Morales-Jiménez, J. Effect of bacterial probiotics bio-encapsulated into Artemia franciscana on weight and length of the shortfin silverside (Chirostoma humboldtianum), and PCR-DGGE characterization of its intestinal bacterial community. Latin american journal of aquatic research 2017, 45, 1031-1043

3. Chauhan, A.; Singh, R. Probiotics in aquaculture: a promising emerging alternative approach. Symbiosis 2019, 77, 99-113, https://doi.org/10.1007/s13199-018-0580-1.

4. Panigrahi, A.; Azad, I.S. Microbial intervention for better fish health in aquaculture: the Indian scenario. Fish Physiology and Biochemistry 2007, 33, 429-440, https://doi.org/10.1007/s10695-007-9160-7. 
5. Gu, M.; Zhang, Z.; Pan, C.; Goulette, T.R.; Zhang, R.; Hendricks, G.; McClements, D.J.; Xiao, H. Encapsulation of Bifidobacterium pseudocatenulatum G7 in gastroprotective microgels: Improvement of the bacterial viability under simulated gastrointestinal conditions. Food Hydrocolloids 2019, 91, 283-289, https://doi.org/10.1016/j.foodhyd.2019.01.040.

6. Wanka, K.M.; Damerau, T.; Costas, B.; Krueger, A.; Schulz, C.; Wuertz, S. Isolation and characterization of native probiotics for fish farming. BMC Microbiology 2018, 18, https://doi.org/10.1186/s12866-0181260-2.

7. Rosas-Ledesma, P.; León-Rubio, J.M.; Alarcón, F.J.; Moriñigo, M.A.; Balebona, M.C. Calcium alginate capsules for oral administration of fish probiotic bacteria: assessment of optimal conditions for encapsulation. Aquaculture Research 2012, 43, 106-116, https://doi.org/10.1111/j.1365-2109.2011.02809.x.

8. Soliman, W.S.; Shaapan, R.M.; Mohamed, L.A.; Gayed, S.S.R. Recent biocontrol measures for fish bacterial diseases, in particular to probiotics, bio-encapsulated vaccines, and phage therapy. Open veterinary journal 2019, 9, 190-195, https://doi.org/10.4314/ovj.v9i3.2.

9. Xia,Y.; Lu, M.; Chen, G.; Cao, J.; Gao, F.; Wang, M.; Liu, Z.; Zhang, D.; Zhu, H.; Yi, M. Effects of dietary Lactobacillus rhamnosus JCM1136 and Lactococcus lactis subsp; lactis JCM5805 on the growth, intestinal microbiota, morphology, immune response and disease resistance of juvenile Nile tilapia, Oreochromis niloticus. F shellfish immun 2018, 76, 368-79. https://doi.org/10.1016/j.fsi.2018.03.020.

10. De, B.C.; Meena, D.K.; Behera, B.K.; Das, P.; Mohapatra, P.D.; Sharma, A.P. Probiotics in fish and shellfish culture, immunomodulatory and ecophysiological responses. Fish phy and biochem 2014, 40, 921-71, https://doi.org/10.1007/s10695-013-9897-0.

11. Krishnaveni, G.; Vignesh, S.; Vidhyalakshmi, N.; Vijay, V.; Ramesh, U. Effects of dietary supplementation of Lactobacillus fermentum URLP18 on growth, innate immunity and survival against Aeromonas hydrophila ATCC 7966 challenge in freshwater fish Cyprinus carpio (common carp). Aquaculture Research 2021, 52, 1160-1176, https://doi.org/10.1111/are.14974.

12. Jantarathin, S.; Borompichaichartkul, C.; Sanguandeekul, R. Microencapsulation of probiotic and prebiotic in alginate-chitosan capsules and its effect on viability under heat process in shrimp feeding. Materials Today: Proceedings 2017, 4, 6166-6172, https://doi.org/10.1016/j.matpr.2017.06.111.

13. Al-Harbi, A.H.; Uddin, N. Bacterial diversity of tilapia (Oreochromis niloticus) cultured in brackish water in Saudi Arabia. Aquaculture 2005, 250, 566-572, https://doi.org/10.1016/j.aquaculture.2005.01.026.

14. Yodsenee, K.; Showpanish, K.; Sonhom, N.; Pilasombut, K.; Prachom, N.; Sathitkowitchai, W.; Buathong, R.; Rumjuankiat, K. Encapsulation of Pediococcus pentosaceus RSU-Nh1 into pectin-sodium alginate and chitosan coating. Tech 2019, 16, 207-222.

15. Pirarat, N. Efficacy of encapsulated yeast (Saccharomyces cerevisiae) against Streptococcosis in tilapia. Chulalo Univ, 2015.

16. Pirarat, N.; Pinpimai, K.; Rodkhum, C.; Chansue, N.; Ooi, E.L.; Katagiri, T.; Maita, M. Viability and morphological evaluation of alginate-encapsulated Lactobacillus rhamnosus GG under simulated tilapia gastrointestinal conditions and its effect on growth performance, intestinal morphology and protection against Streptococcus agalactiae. Animal Feed Science and Technology 2015, 207, 93-103, https://doi.org/10.1016/j.anifeedsci.2015.03.002.

17. M-Ghoname, R.; S. El-sayed, H.; A. Ghozlan, H.; A. Sabry, S. Application of probiotic bacteria for the improvement of sea bream (Sparus aurata) larval production. Egyptian Journal of Aquatic Biology and Fisheries 2020, 24, 371-398, https://doi.org/10.21608/EJABF.2020.70859.

18. Thomas, J. Use of Probiotics as a Feed in Aquaculture: A Review. Chem Tech Inform Chem App 2019, 317, https://doi.org/10.1201/9781351247450-1.

19. Ibrahem, M.D. Evolution of probiotics in aquatic world: Potential effects, the current status in Egypt and recent prospectives. Journal of Advanced Research 2015, 6, 765-791, https://doi.org/10.1016/j.jare.2013.12.004.

20. Bevilacqua, A.; Campaniello, D.; Speranza, B.; Racioppo, A.; Altieri, C.; Sinigaglia, M.; Corbo, M.R. Microencapsulation of Saccharomyces cerevisiae into Alginate Beads: A Focus on Functional Properties of Released Cells. Foods 2020, 9, https://doi.org/10.3390/foods9081051.

21. Loh, J.Y.; Chan, H.K.; Yam, H.C.; In, L.L.A.; Lim, C.S.Y. An overview of the immunomodulatory effects exerted by probiotics and prebiotics in grouper fish. Aquaculture International 2020, 28, 729-750, https://doi.org/10.1007/s10499-019-00491-2.

22. Scaramuzzi, R.J.; Campbell, B.K.; Downing, J.A.; Kendall, N.R.; Khalid, M.; Muñoz-Gutiérrez, M.; Somchit, A. A review of the effects of supplementary nutrition in the ewe on the concentrations of reproductive and metabolic hormones and the mechanisms that regulate folliculogenesis and ovulation rate. Reproduction, nutrition, development 2006, 46, 339-354, https://doi.org/10.1051/rnd:2006016.

23. Xia, Y.; Yu, E.; Lu, M.; Xie, J. Effects of probiotic supplementation on gut microbiota as well as metabolite profiles within Nile tilapia, Oreochromis niloticus. Aquaculture 2020, 527, https://doi.org/10.1016/j.aquaculture.2020.735428.

24. Carnevali.O.; Maradonna. F.; Gioacchini. G.; Integrated control of fish metabolism, well-being and reproduction: the role of probiotic. Aqua 2017, 472, 144-155, https://doi.org/10.1016/j.aquaculture.2016.03.037. 
25. Lieke, T.; Meinelt, T.; Hoseinifar, S.H.; Pan, B.; Straus, D.L.; Steinberg, C.E.W. Sustainable aquaculture requires environmental-friendly treatment strategies for fish diseases. Reviews in Aquaculture 2020, 12, 943965, https://doi.org/10.1111/raq.12365.

26. Abasali, H.; Mohamad, S. Effect of dietary probiotic level on the reproductive performance of female platy Xiphophorus maculatus. Agri J 2011, 6, 119-23, https://doi.org/10.3923/aj.2011.119.123.

27. Rezaei-Aminlooi, .V.; Ahmadifard, N.; Tukmechi, A.; Agh, N. Improvement of reproductive indices, lysozyme activity, and disease resistance in live-bearing ornamental fish, Poecilia latipinna using Artemia supplementation with treated yeast cell, Saccharomyces cerevisiae. Aqua $R$ 2019, 50, 72-9, https://doi.org/10.1111/are.13869.

28. Vílchez, M.C.; Santangeli, S.; Maradonna, F.; Gioacchini, G.; Verdenelli, C.; Gallego, V.; Peñaranda, D.S.; Tveiten, H.; Pérez, L.; Carnevali, O.; Asturiano, J.F. Effect of the probiotic Lactobacillus rhamnosus on the expression of genes involved in European eel spermatogenesis. Theriogenology 2015, 84, 1321-1331, https://doi.org/10.1016/j.theriogenology.2015.07.011.

29. Carnevali, O.; Avella, M.A.; Gioacchini, G. Effects of probiotic administration on zebrafish development and reproduction. General and Comparative Endocrinology 2013, 188, 297-302, https://doi.org/10.1016/j.ygcen.2013.02.022.

30. Rahman, M.L.; Akhter, S.; Mallik, M.K.; Rashid, I. Probiotic enrich dietary effect on the reproduction of butter catfish, Ompok pabda (Hamilton, 1872). Int J Cur R Life Sci 2018, 7, 866-73.

31. Egerton, S.; Culloty, S.; Whooley, J.; Stanton, C.; Ross, R.P. The gut microbiota of marine fish. Front micro 2018, 9, https://doi.org/10.3389/fmicb.2018.00873.

32. Yi, C.C.; Liu, C.H.; Chuang, K.P.; Chang, Y.T.; Hu, S.Y. A potential probiotic Chromobacterium aquaticum with bacteriocin-like activity enhances the expression of indicator genes associated with nutrient metabolism, growth performance and innate immunity against pathogen infections in zebrafish (Danio rerio). Fish shellfish immuno 2019, 93, 124-134, https://doi.org/10.1016/j.fsi.2019.07.042.

33. Makridis, P.; Kokou, F.; Bournakas, C.; Papandroulakis, N.; Sarropoulou, E. Isolation of Phaeobacter sp. from Larvae of Atlantic Bonito (Sarda sarda) in a Mesocosmos Unit, and Its Use for the Rearing of European Seabass Larvae (Dicentrarchus labrax $\quad$ L.). Microorg https://doi.org/10.3390/microorganisms9010128.

34. Sharifuzzaman, S.M.; Austin, B. Probiotics for disease control in aquaculture. Diag Cont Disea of Fish Shellfish 2017, 189-222, https://doi.org/10.1002/9781119152125.ch8 .

35. Zorriehzahra, M.J.; Delshad, S.T.; Adel, M.; Tiwari, R.; Karthik, K.; Dhama, K.; Lazado, C.C. Probiotics as beneficial microbes in aquaculture: an update on their multiple modes of action: a review. Vet quart 2016, 36, 228-41, https://doi.org/10.1080/01652176.2016.1172132.

36. Hosain, M. A.; Liangyi, X. Impacts of probiotics on feeding technology and its application in aquaculture. $J$ Aqua Fisheries \& Fish Sci 2020, 3,174-85, https://doi.org/10.25177/jaffs.3.1.ra.622 .

37. Iwashita, M.K.; Addo, S.; Terhune, J.S.Use of pre-and probiotics in finfish aquaculture. Feed Feeding Prac Aqua 2015, 235-249, https://doi.org/10.1016/B978-0-08-100506-4.00009-X.

38. Kumaree, K.K.; Akbar, A.; Anal, A.K. Bioencapsulation and application of Lactobacillus plantarum isolated from catfish gut as an antimicrobial agent and additive in fish feed pellets. Ann micro 2015, 65, 1439-45, https://doi.org/10.1007/s13213-014-0982-0 .

39. Raghavan, K.; Lakshmi, G.B. Formulation of Probiotic-Based Functional Fish Feeds: ECO-Friendly Approach. Tech Pro M Foods, From Water to Fork: Bio Compd, Ind App, Gen 2019, 307.

40. Dhont, J.; Dierckens, K.; Støttrup, J.; Van-Stappen, G.; Wille, M.; Sorgeloos, P. Rotifers, Artemia and copepods as live feeds for fish larvae in aquaculture. Adv aqua hatch tech 2013, 157-202, https://doi.org/10.1533/9780857097460.1.157.

41. Carter, C.G. 13 - Feeding in hatcheries. In: Feed and Feeding Practices in Aquaculture. Davis, D.A. Ed. Woodhead Publishing: Oxford, 2015; pp. 317-348, https://doi.org/10.1016/B978-0-08-100506-4.00013-1.

42. Gopakumar, G.; Ignatius, B. Live feed production for marine aquaculture status, problems and prospects. 2006.

43. Motlagh, H.R.; Farhangi, M.; Rafiee, G.; Noori, F. Modulating gut microbiota and digestive enzyme activities of Artemia urmiana by administration of different levels of Bacillus subtilis and Bacillus licheniformis. Aqua Int 2012, 20, 693-705, https://doi.org/10.1007/s10499-012-9497-5.

44. Aydın, F.; Çek-Yalnız, Ş. Effect of probiotics on reproductive performance of fish. Natur and Eng Sci 2019, 4, 153-162, https://doi.org/10.28978/nesciences.567113.

45. Cordero, H.; Guardiola, F.A.; Tapia-Paniagua, S.T.; Cuesta, A.; Meseguer, J.; Balebona, M.C.; Moriñigo, M.Á.; Esteban, M.Á. Modulation of immunity and gut microbiota after dietary administration of alginate encapsulated Shewanella putrefaciens Pdp11 to gilthead seabream (Sparus aurata L.). Fish shellfish immuno 2015, 45,608-18, https://doi.org/10.1016/j.fsi.2015.05.010.

46. Prado, S.; Barja, J.L.; Luzardo, A.; Dubert, J.; Blanco, J. Encapsulation of live marine bacteria for use in aquaculture facilities and process evaluation using response surface methodology. Appl Micro Biotech 2020, 104, 1993-2006, https://doi.org/10.1007/s00253-019-10332-0.

47. Utami, D.; Widanarni, W.; Suprayudi, M. Administration of Microencapsulated Probiotic at Different Doses to Control Streptococcosis in Tilapia (Oreochromis niloticus). Microbiology Indonesia 2015, 9, 17-24. 
48. Makridis, P.; Jon Fjellheim, A.; Skjermo, J.; Vadstein, O. Colonization of the gut in first feeding turbot by bacterial strains added to the water or bioencapsulated in rotifers. Aquaculture International 2000, 8, 367380, https://doi.org/10.1023/a:1009251531832 .

49. Vázquez Silva, G.; J, J.; Concha, B.; Gonz’alez-V’azquez, R.; Mayorga, L.; Azaola, A. Bioencapsulation of Bifidobacterium animalis and Lactobacillus johnsonii in Artemia franciscana as feed of charal (Chirostoma jordani) larvae. Revista Mexicana de Ingeniería Química 2016, 15, 809-818.

50. Lee, C.-S. Biotechnological advances in finfish hatchery production: a review. Aquaculture 2003, 227, 439458, https://doi.org/10.1016/S0044-8486(03)00522-2.

51. Chiu, S.-T.; Tsai, R.-T.; Hsu, J.-P.; Liu, C.-H.; Cheng, W. Dietary sodium alginate administration to enhance the non-specific immune responses, and disease resistance of the juvenile grouper Epinephelus fuscoguttatus. Aquaculture 2008, 277, 66-72, https://doi.org/10.1016/j.aquaculture.2008.01.032.

52. Hasan, K.N.; Banerjee, G. Recent studies on probiotics as beneficial mediator in aquaculture: a review. The $J$ B and Appl Zoo 2020, 81, 1-16, https://doi.org/10.1186/s41936-020-00190-y

53. Okoliegbe, I.; Solomon, L.; Dick, A.-A. Exploiting Microbial Communities Associated with Marine Fish: An Indispensable Approach to Sustainable Aquaculture. Nature and Science 2017, 15, 84-91, https://doi.org/10.7537/marsnsj150417.12.

54. Shefat, S.H. Probiotic strains used in aquaculture. Int Res J Micro 2018, 7, 43-55, https://doi.org/10.14303/irjm.2018.023.

55. Stoica, M.; Alexe, P.; Valsame, M. Microencapsulation of biological compounds for cul-tured fish diet. A brief review. J Agro Pro and Tech 2016, 22, 1-6.

56. Yao, M.; Xie, J.; Du, H.; McClements, D.J.; Xiao, H.; Li, L. Progress in microencapsulation of probiotics: A review. Comprehensive Reviews in Food Science and Food Safety 2020, 19, 857-874, https://doi.org/10.1111/1541-4337.12532.

57. Giorgia, G.; Elia, C.; Andrea, P.; Cinzia, C.; Stefania, S.; Ana, R.; Daniel, M.L.; Ike, O.; Oliana, C. Effects of Lactogen 13, a New Probiotic Preparation, on Gut Microbiota and Endocrine Signals Controlling Growth and Appetite of Oreochromis niloticus Juveniles. Microbial Ecology 2018, 76, 1063-1074, https://doi.org/10.1007/s00248-018-1177-1.

58. Pinpimai, K.; Rodkhum, C.; Chansue, N.; Katagiri, T.; Maita, M.; Pirarat, N. The study on the candidate probiotic properties of encapsulated yeast, Saccharomyces cerevisiae JCM 7255, in Nile Tilapia (Oreochromis niloticus). Research in Veterinary Science 2015, 102, 103-111, https://doi.org/10.1016/j.rvsc.2015.07.021.

59. Sun,Y.Z.; Yang, H.L.; Huang, K.P.; Ye, J.D.; Zhang, C.X. Application of autochthonous Bacillus bioencapsulated in copepod to grouper Epinephelus coioides larvae. Aqua 2013, 392, 44-50, https://doi.org/10.1016/j.aquaculture.2013.01.037.

60. Al Mamun, M.A.; Nasren, S.; Rathore, S.; Sidiq, M.J.; Dharmakar, P.; K V, A. Assessment of Probiotic in Aquaculture: Functional Changes and Impact on Fish Gut. Microbiology Research Journal International 2019, 1-10, https://doi.org/10.9734/mrji/2019/v29i130156.

61. Avella, M.A.; Gioacchini, G.; Decamp, O.; Makridis, P.; Bracciatelli, C.; Carnevali, O. Application of multispecies of Bacillus in sea bream larviculture. Aquaculture 2010, 305, 12-19, https://doi.org/10.1016/j.aquaculture.2010.03.029.

62. Benetti, D.D.; Sardenberg, B.; Welch, A.; Hoenig, R.; Orhun, M.R.; Zink, I. Intensive larval husbandry and fingerling production of cobia Rachycentron canadum. Aquaculture 2008, 281, 22-27, https://doi.org/10.1016/j.aquaculture.2008.03.030.

63. Carnevali, O.; de Vivo, L.; Sulpizio, R.; Gioacchini, G.; Olivotto, I.; Silvi, S.; Cresci, A. Growth improvement by probiotic in European sea bass juveniles (Dicentrarchus labrax, L.), with particular attention to IGF-1, myostatin and cortisol gene expression. Aquaculture 2006, 258, 430-438, https://doi.org/10.1016/j.aquaculture.2006.04.025.

64. Gatesoupe, F.-J. Probiotic and formaldehyde treatments of Artemia nauplii as food for larval pollack, Pollachius pollachius. Aquaculture 2002, 212, 347-360, https://doi.org/10.1016/S0044-8486(02)00138-2.

65. Cámara-Ruiz, M.; Balebona, M.C.; Moriñigo, M.Á.; Esteban, M.Á. Probiotic Shewanella putrefaciens (SpPdp11) as a Fish Health Modulator: A Review. Microorganisms 2020, 8, https://doi.org/10.3390/microorganisms8121990.

66. Makridis, P.; Bergh, Ø.; Skjermo, J.; Vadstein, O. Addition of bacteria bioencapsulated in Artemia metanauplii to a rearing system for halibut larvae. Aquaculture International 2001, 9, 225-235, https://doi.org/10.1023/a:1016815929846.

67. Suzer, C.; Çoban, D.; Kamaci, H.O.; Saka, Ş.; Firat, K.; Otgucuoğlu, Ö.; Küçüksari, H. Lactobacillus spp. bacteria as probiotics in gilthead sea bream (Sparus aurata, L.) larvae: Effects on growth performance and digestive enzyme activities. Aquaculture 280, 2008, https://doi.org/10.1016/j.aquaculture.2008.04.020.

68. Tinh, N.T.N.; Yen, V.H.N.; Dierckens, K.; Sorgeloos, P.; Bossier, P. An acyl homoserine lactone-degrading microbial community improves the survival of first-feeding turbot larvae (Scophthalmus maximus L.). Aquaculture 2008, 285, 56-62, https://doi.org/10.1016/j.aquaculture.2008.08.018. 
69. Touraki, M.; Karamanlidou, G.; Koziotis, M.; Christidis, I. Antibacterial effect of Lactococcus lactis subsp. lactis on Artemia franciscana nauplii and Dicentrarchus labrax larvae against the fish pathogen Vibrio anguillarum. Aquaculture International 2013, 21, 481-495, https://doi.org/10.1007/s10499-012-9579-4.

70. Villamil, L.; Figueras, A.; Planas, M.; Novoa, B. Pediococcus acidilactici in the culture of turbot (Psetta maxima) larvae: Administration pathways. Aquaculture 2010, 307, 83-88, https://doi.org/10.1016/j.aquaculture.2010.07.004.

71. Xan, L. Advances in the seed production of Cobia Rachycentron canadum in Vietnam. Aqua Asia $2005,10$.

72. Teoh, L.; Mirhosseini, H.; Shuhaimi, M.; Yazid, A.; Manap, A. Tolerance of free and encapsulated probiotics towards heat treatment and high sodium concentration. Journal of Food, Agriculture and Environment 2011, 9, 69-73.

73. Chen, S.-W.; Liu, C.-H.; Hu, S.-Y. Dietary administration of probiotic Paenibacillus ehimensis NPUST1 with bacteriocin-like activity improves growth performance and immunity against Aeromonas hydrophila and Streptococcus iniae in Nile tilapia (Oreochromis niloticus). Fish \& shellfish immunology 2019, 84, 695703, https://doi.org/10.1016/j.fsi.2018.10.059. 